\title{
PERANAN DAN KEDUDUKAN LEMBAGA BANTUAN HUKUM SEBAGAI ACCESS TO JUSTICE BAGI ORANG MISKIN
}

\author{
Mustika Prabaningrum Kusumawati \\ Fakultas Hukum Universitas Islam Indonesia \\ Jl. Tamansiswa No. 158 Yogyakarta, (0274) 379178 \\ Email: mustika.praba@gmail.com
}

\begin{abstract}
Legal aid is a concept of solution for the needs of society over the idiom of "law sharp down, law blunt up". The existence of Law Number 16 Year 2011 on the Legal Aid relates to the law reformation agenda of granting the access to justice and the right to fair trial towards Indonesian citizens, among others by giving legal assistance.

The method used is normative-empiric, by not only analysing Law Number 16 Year 2011 on the Legal Aid, but also analyse the implementation of Law on Legal Aid and its role in the legal aid institution of giving access to justice.

The existence of legal aid institutions are expected to be the new hope in the mid of society in defending their rights before the law, either non-litigation process or litigation process. It is undeniable that the negative stigma of society towards the process of access to justice in Indonesia is very strong and enormous then creates a distrust of Indonesian legal system. The result of the research is the legal aid institutions have a great role in granting access to justice, thus they are not only as new hope of society but also the real evidence of justice towards everyone before the law.
\end{abstract}

Key words: role, legal aid institution, access to justice

\begin{abstract}
Abstrak
Bantuan hukum merupakan suatu konsep jawaban terhadap adanya kebutuhan masyarakat atas adagium "hukum tajam ke bawah, hukum tumpul ke atas". Keberadaan Undang-undang Nomor 16 Tahun 2011 tentang Bantuan Hukum tidak lepas dari agenda reformasi hukum yang memberikan hak bagi warga negaranya untuk mendapatkan keadilan (access to justice) dan hak untuk mendapatkan peradilan yang adil dan tidak memihak (fair trial) diantaranya melalui pemberian bantuan hukum.

Metode yang dipergunakan adalah normatif-empiris, dimana selain mengkaji peraturan tertulis yakni Undang-undang Nomor 16 Tahun 2011 tentang Bantuan Hukum, juga dikaji terkait implementasi ketentuan hukum normatif Undang-undang Nomor 16 Tahun 2011 tentang Bantuan Hukum dalam aksinya dalam peristiwa lembaga bantuan hukum dalam access to justice penyelenggaraan bantuan hukum.

Tujuan dibentuknya Undang-undang Nomor 16 Tahun 2011 tentang Bantuan Hukum ini menjadikan sebuah payung hukum bagi lembaga-lembaga bantuan hukum untuk lebih dapat bergerak bebas dan leluasa tetapi tetap dalam koridor hukum di dalam memberikan bantuan hukum pada masyarakat luas khususnya masyarakat yang tergolong masyarakat tidak mampu. Banyaknya lembaga-lembaga bantuan hukum yang bermunculan sangat diharapkan peran serta yang nyata agar dapat menjadi asa baru di tengah keputusasaan masyarakat awam dalam memperjuangkan hak-haknya di mata hukum, baik dalam memperjuangkan permasalahan
\end{abstract}


hukum yang di hadapi secara non litigasi (di luar pengadilan) maupun secara litigasi (di dalam pengadilan). Tidak dapat dipungkiri, stigma negatif masyarakat terhadap proses mencari keadilan di negeri tercinta, Indonesia sangat kuat dan besar sehingga muncul sebuah ketidakpercayaan terhadap dunia peradilan kita. Oleh sebab itulah diperoleh hasil bahwa lembaga bantuan hukum memiliki andil yang besar dalam access to justice sehingga tidak hanya dapat menumbuhkan harapan baru di dalam dunia peradilan tetapi juga menjadi bukti nyata akan keadilan yang sama bagi siapa pun di muka hukum.

Kata kunci: peranan, lembaga bantuan hukum, access to justice

\section{Latar Belakang}

Indonesia merupakan negara yang menganut sistem negara hukum (rule of law). Negara hukum di sini mengisyaratkan bahwa dimana kedudukan seluruh warganya sama di depan hukum tanpa terkecuali. Selain menganut sistem rule of law, Indonesia juga merupakan negara yang berdasar hukum (recht staat) Dasar pijakan bahwa negara Indonesia adalah negara hukum tertuang dalam Undangundang Dasar $1945^{1}$, yang menyebutkan bahwa "Negara Indonesia adalah Negara Hukum". Dimasukkannya ketentuan ini ke dalam bagian pasal Undang-undang Dasar 1945 menunjukkan semakin kuatnya dasar hukum serta menjadi amanat negara, bahwa negara Indonesia adalah dan harus merupakan negara hukum yang berarti bahwa segala bentuk persoalan yang menyangkut urusan antara warga negara dengan warga negara atau warga negara dengan negara (pemerintah), harus didasarkan pada hukum dan peraturan perundang-undangan yang berlaku di Indonesia. Sebagai konsekuensinya, maka setiap warga negara juga berhak mendapatkan perlindungan hukum yang sama tanpa terkecuali.
Sistem rule of law terlihat sekali dalam prakteknya tidak dapat diterapkan dengan baik di dalam kehidupan bernegara Indonesia. Sistem rule of law yang mengharuskan adanya persamaan kedudukan warga negara di depan hukum justru menjadi jurang pemisah antara rakyat dengan kaum-kaum yang memiliki uang dan jabatan yang dimana mereka samasama berstatus sebagai warga negara.

Kemiskinan merupakan permasalahan yang sangat kompleks, yang tidak hanya terbatas pada permasalahan ekonomi saja tetapi juga berkaitan dengan permasalahan di bidang lain. Kebijakan dari pemerintah sangat dibutuhkan di dalam membantu memecahkan persoalan terkait kemiskinan pada bidang-bidang lainnya, contohnya dalam bidang hukum. Memang benar, kemiskinan secara global diartikan sebagai kemiskinan dalam batas materi, yang dapat diukur dengan nominal sejumlah uang dalam bentuk rupiah atau dapat dikaitkan pada nominal Upah Minimum Regional (UMR) di setiap-setiap daerah di Indonesia. Akan tetapi, ketika kemiskinan bersinggungan dengan bidang hukum, makna kemiskinan tersebut mengandung makna yang tidak hanya

$1 \quad$ Pasal 1 ayat 3 Undang-Undang Dasar 1945. 
sebatas pada sisi materiil semata tetapi juga berhubungan dengan keterbatasan masyarakat untuk mendapatkan akses terhadap keadilan yang notabene merupakan hak mereka. Due process of law (proses hukum yang adil) yang ada selama ini pada kenyataannya tidak sesuai dengan makna istilah itu sendiri.

Sistem rule of law yang menuntut kesamaan kedudukan warga negara di muka hukum ini terkadang kurang diapresiasi oleh warga negara sendiri khususnya bagi rakyat kecil yang tersandung kasus-kasus hukum. Sebagian besar dari mereka justru lebih ikhlas atau rela hak-hak mereka dibuang percuma karena mereka berpendapat bahwa memperjuangkan hak-hak mereka dalam kasus hukum justru akan merugikan mereka dalam perspektif materi. Hal ini disebabkan karena mereka menyaksikan maraknya beritaberita yang beredar di berbagai media massa yang menunjukkan bahwa tersandung kasus hukum harus mengeluarkan biaya yang tidak sedikit dan parahnya lagi bahkan muncul anggapan bahwa hukum itu dapat dibeli. Di sinilah timbul sebuah pertanyaan, sejauh mana peranan lembaga bantuan hukum dalam access to justice penyelenggaraan bantuan hukum bagi kaum miskin.

Negara memahami permasalahan ini dengan dikeluarkannya Undang-undang Nomor 16 Tahun 2011 tentang Bantuan Hukum sebagai tindakan nyata dalam melindungi persamaan kedudukan warga negaranya di muka hukum. Undang-undang Nomor 16 Tahun 2011 tentang Bantuan Hukum ini mencakup ketersediaan dana bantuan hukum yang dapat diakses oleh para advokat yang telah memberikan bantuan hukum bagi rakyat miskin, demikian juga bagi lembaga bantuan hukum. Sehingga diharapkan dengan keberadaan Undang-undang Nomor 16 Tahun 2011 tentang Bantuan Hukum, lembaga bantuan hukum dalam access to justice dapat memberikan peranan lebih demi terciptanya penyelenggaraan bantuan hukum di Indonesia.

\section{Pembahasan}

Indonesia merupakan negara kepulauan yang termasuk dalam kategori salah satu negara berpenduduk terbanyak di dunia setelah Cina, India dan Amerika Serikat. Dengan menjadi salah satu negara berpenduduk terbanyak, nyatanya Indonesia terdiri dari berbagai golongan, baik golongan kelas menengah atas, golongan menengah dan golongan menengah ke bawah. Pembagian golongan atau stratifikasi sosial sesuai dengan pola yang diberikan oleh stratifikasi Aristoteles dimana stratifikasi ini terdiri dari golongan pertama (merupakan kelompok terkecil dalam masyarakat, yaitu pengusaha, tuan tanah dan bangsawan), golongan kedua (merupakan golongan yang cukup banyak terdapat di dalam masyarakat. Mereka terdiri dari para pedagang) dan golongan ketiga (merupakan golongan terbanyak dalam masyarakat yang kebanyakan adalah rakyat biasa). Ketimpangan ini, mau tidak mau berdampak pula pada adagium hukum tajam ke bawah, hukum tumpul ke atas. Hal 
ini disebabkan karena kenyataannya banyak sekali masyarakat awam yang menyaksikan di berbagai media bahwa keadilan dapat dibeli oleh golongan atas. Walaupun semestinya, hukum itu sendiri adil bagi semua tanpa terkecuali karena semua orang memiliki kedudukan yang sama di hadapan hukum.

Berbagai latar belakang atau faktor utama yang menjadi penyebab belum tercapainya access to justice di dalam masyarakat pencari keadilan perlu ditelusuri demi tercapainya access to justice bagi seluruh masyarakat tanpa terkecuali. Sehingga sejauh mana peranan lembaga bantuan hukum sebagai wadah access to justice di dalam penyelenggaraan bantuan hukum di Indonesia juga perlu ditelusuri.

Indonesia merupakan negara yang menganut sistem negara hukum (rule of law). Negara hukum di sini mengisyaratkan bahwa dimana kedudukan seluruh warganya sama di depan hukum tanpa terkecuali. Selain menganut sistem rule of law, Indonesia juga merupakan negara yang berdasar hukum (recht staat) yang berarti bahwa segala bentuk persoalan yang menyangkut urusan antara warga negara dengan warga negara atau warga negara dengan negara (pemerintah), harus didasarkan pada hukum dan peraturan perundang-undangan yang berlaku di Indonesia. Sebagai konsekuensi atas dianutnya sistem rule of law dan recht staat maka setiap warga negara juga berhak mendapatkan perlindungan hukum yang sama tanpa terkecuali.
Thomas Hobbes berpandangan bahwa keadilan sama dengan hukum positif yang dibuat oleh penguasa. Pandangan ini mengandung konsekuensi bahwa norma hukum positif adalah satu-satunya alat untuk menilai baik-buruknya, adil-tidak-adil. ${ }^{2}$

Menurut Ni'matul Huda, pada dasarnya, persaman antara konsep recht staat dengan konsep rule of law, yaitu: pada dasarnya kedua konsep itu mengarahkan dirinya pada satu sasaran yang utama, yakni pengakuan dan perlindungan terhadap hak-hak asasi manusia. Sedangkan perbedaan antara konsep recht staat dengan konsep rule of law, yaitu:

a. Konsep recht staat lahir dari suatu perjuangan menentang absolutisme sehingga sifatnyarevolusioner, sebaliknya konsep rule of law berkembang secara evolusioner.

b. Konsep recht staat bertumpu atas sistem hukum kontinental yang disebut civil law, sedangkan konsep rule of law bertumpu atas sistem hukum yang disebut common law. Karakteristik civil law adalah administratif, sedangkan karakteristik common law adalah judicial.

Prinsip ini berdampak pada perlakuan yang sama bagi warga negara termasuk mereka kaun miskin yang sedang menghadapi permasalahanhukum.Apabilaorangkayadapat dengan mudah membayar jasa advokat untuk mendampinginya dalam proses peradilan, maka orang miskin pun memiliki hak yang sama untuk didampingin dan mendapatkan

2 Mahrus Ali, Membumikan Hukum Progresif, Cetakan Ke-1, (Yogyakarta: Aswaja Pressindo, 2013), hlm. 6. 
jasa bantuan hukum dalam kerangka bantuan hukum yang ada di Indonesia. Ditegaskan pula bahwa akses terhadap keadilan sebagai kesempatan atau kemampuan setiap warga negara tanpa membedakan latar belakangnya (ras, agama, keturunan, pendidikan atau tempat lahirnya) untuk memperoleh keadilan melalui lembaga peradilan. ${ }^{3}$

Pasal 34 ayat (1) UUD 1945 yang menyebutkan bahwa fakir miskin dan anak terlantar dipelihara oleh negara memiliki makna bahwa kata "dipelihara" tidak hanya diberikan kebutuhan sebatas sandang dan pangan semata, akan tetapi juga diberikan akses pada keadilan berupa pemberian bantuan hukum meskipun cuma-cuma. Dengan kata lain, dapat dikatakan bahwa prinsip equality before the law selain mengandung makna persamaan kedudukan di muka huku, oleh Rhode diartika sebagai persamaan akses terhadap hukum dan keadilan.

Sistem rule of law di Indonesia terlihat sekali belum dapat diterapkan dengan baik. Sistem rule of law yang mengharuskan adanya persamaan kedudukan warga negara di depan hukum justru menjadi jurang pemisah antara rakyat dengan kaum-kaum yang memiliki uang dan jabatan yang dimana mereka sama-sama berstatus sebagai warga negara. Sistem rule of law yang menuntut kesamaan kedudukan warga negara di muka hukum ini terkadang kurang diapresiasi oleh warga negara sendiri khususnya bagi rakyat kecil yang tersandung kasus-kasus hukum. Sebagian besar dari mereka justru lebih ikhlas atau rela hak-hak mereka dibuang percuma karena mereka berpendapat bahwa memperjuangkan hak-hak mereka dalam kasus hukum justru akan merugikan mereka dalam perspektif materi. Hal ini disebabkan karena mereka menilai, tersandung kasus hukum harus mengeluarkan biaya yang tidak sedikit dan parahnya lagi bahkan muncul anggapan bahwa hukum itu dapat dibeli. Di sinilah timbul sebuah pertanyaan, sejauh mana peranan lembaga bantuan hukum sebagai access to justice dalam penyelenggaraan bantuan hukum.

Konflik atau sengketa yang timbul di dalam kehidupan bermasyarakat bersumber dari adanya permasalahan yang disebabkan perbedaan antara das Sollen (yang diinginkan) dan das Sein (yang terjadi). Di dalam kehidupan bermasyarakat tentunya sangat mendambakan kedamaian yang pasti dapat terwujud apabila tidak terjadi pertentangan kepentingan antar masyarakat, baik antar individu satu dengan yang lain maupun antar kelompok satu dengan yang lain. Demi terhindar dari gesekan-gesekan pertentangan dan demi mewujudkan kedamaian tersebut, masyarakat membutuhkan suatu kaidah atau norma yang harus ditaati pula oleh mereka.

Norma hukum sebagai salah satu norma yang ada di dalam masyarakat yang berperan untuk mengatur segala tingkah laku manusia disertai dengan ancaman sanksi apabila

3 Djohanjah, Akses Pada Keadilan, Makalah pada Pelatihan HAM Jejaring Komisi Yudisial, Bandung: 30 Juni - 3 Juli 2010. 
norma ini dilanggar, dibentuk tidak dengan tanpa tujuan. Selain untuk mengatur tingkah laku manusia, norma hukum ini bertujuan menciptakan suasana aman, damai dan adil. Tidak dapat dibayangkan apabila pada suatu masyarakat tidak terdapat norma hukum, maka dapat dipastikan tidak akan terjamin kemanan, kedamaian dan keadilan pada masyarakat tersebut.

Negara berdasarkan Undang-undang Nomor 16 Tahun 2011 tentang Bantuan Hukum menjamin hak konstitusional bagi setiap orang atau warga negaranya untuk mendapatkan pengakuan, jaminan, perlindungan dan kepastian hukum yang adil serta perlakuan yang sama di hadapan hukum sebagai sarana perlindungan hak asasi manusia.

Dalam prakteknya, penegakan persamaan di muka hukum sulit tercapai terutama jika yang tersandung kasus hukum adalah golongan masyarakat yang tidak mampu atau miskin yang pada umumya tidak mengetahui hukum (buta hukum). Mereka yang tidak mampu bahkan buta hukum ini terkadang tidak mengetahui hak-hak mereka yang pada dasarnya sudah diatur dalam undangundang karena sebagian besar dari mereka terpaku dengan anggapan bahwa ketika mereka ingin membela hak-hak mereka, mereka harus mengeluarkan biaya besar yang mungkin untuk makan saja mereka masih kesulitan. Hal ini dilatarbelakangi oleh sangat minimnya sosialisasi terkait hak-hak mereka ketika menghadapi kasus hukum. Terlebih lagi, maraknya stigma mahalnya biaya untuk membayar jasa advokat atau pengacara.

Pengadilan sebagai pelaksana hukum adalah suatu lembaga yang akan memberikan keadilan bagi mereka yang mencari keadilan, tidak peduli siapapun dan bagaimanapun latar belakangnya. Namun pada kenyataannya hukum sejak semula selalu mengandung potensi untuk cenderung memberikan keuntungan kepada mereka dari golongan yang lebih mampu secara finansial. ${ }^{4}$

Dalam sistem peradilan di Indonesia, tidak sedikit dari putusan-putusan pengadilan yang justru jauh dari dari harapan masyarakat. Ia hanya mengacu pada aturan-aturan formal belaka. Pengadilan yang seharusnya menjadi tempat untuk menemukan keadilan berubah menjadi medan perang untuk mencari kemenangan (to win the case). ${ }^{5}$ Pada prinsipnya mekanisme penyelesaian perkara melalui pengadilan bersifat win lose solution.

Konsep access to justice terhadap keadilan tidak semata terbatas pada akses terhadap advokat ataupun akses terhadap pengadilan, tetapi juga akses terhadap Ombudsman dan lembaga-lembaga "keadilan yang lain”. Konsep access to justice yang ada di Indonesia bertitik tumpu kepada tujuan yakni sistem hukum yang dapat diakses oleh seluruh kalangan warga negara serta tujuan bahwa sistem hukum seharusnya dapat menghasilkan ketentuan atau keputusan yang adil bagi

4 Satjipto Rahardjo, Sisi-Sisi Lain dari Hukum di Indonesia, (Jakarta: Buku Kompas, 2003), hlm. 177.

5 Antonius Sudirman, Hati Nurani Hakim dan Putusannya, (Bandung: Citra Aditya Bakti, 2007), hlm. 53-54. 
seluruh kalangan warga negara baik individu maupun kelompok. ${ }^{6}$

Di dalam konsep access to justice ini pula, keadilan diartikan sebagai sebuah keadaan dan proses di mana negara menjamin akan terpenuhinya hak-hak dasar bagi warga negaranya yakni hak dasar berdasarkan UUD 1956 serta prinsip-prinsip universal hak asasi manusia dan menjamin akses bagi setiap warga negara agar dapat memiliki kemampuan untuk mengetahui, memahami, menyadari dan menggunakan hak-hak dasar tersebut melalui lembaga-lembaga formal maupun informal yang didukung oleh mekanisme keluhan publik yang baik dan responsif agar diperoleh manfaat yang optimal dan memperbaiki kualitas kehidupannya sendiri.

Ketidakpahaman kaum masyarakat tersebut dapat dikatakan melahirkan suatu ketidakadilan sebab negara sendirilah yang menjamin adanya persamaan di muka hukum. Untuk menghapus ketidakadilan yang menodai asas persamaan di muka hukum maka peranan lembaga bantuan hukum sangat dibutuhkan bahkan telah diatur dalam Undang-undang Nomor 16 Tahun 2011 tentang Bantuan Hukum dimana dalam Undang-undang Nomor 16 Tahun 2011 tentang Bantuan Hukum di sini juga menjadikan lembaga bantuan hukum sebagai suatu access to justice bagi masyarakat yang tidak mampu bahkan bagi masyarakat yang buta hukum.
Rawls di dalam A Theory Of Justice memberikan suatu konsep keadilan sosial, dimana keadilan sosial dipandang sebagai sebuah instansi pertama, standar dari mana aspek distributif suatu struktur dasar masyarakat dinilai. ${ }^{7}$ Sebuah konsepsi Rawls ini menetapkan cara penempatan hak-hak dan kewajiban lembaga-lembaga dasar masyarakat, serta cara menetapkan pendistribusian yang sesuai dengan berbagai nikmat dan beban dari kerjasama sosial. Lebih lanjut, Rawls memberikan konsepsi bahwa seluruh kenikmatan primer berupa kemerdekaan dan kesempatan, pendapatan dan kekayaan serta dasar-dasar kehormatan diri, haruslah dibagikan secara sama.

Unsur-unsur pokok keadilan sosial menurut Rawls mencakup (1) prinsip pokok keadilan sosial adalah equality atau kesamaan; yaitu: (2) kesamaan dalam distribusi; atas (3) nikmat-nikmat primer (primary goods); namun (4) ketidaksamaan (inequalities) dapat ditoleransi sejauh menguntungkan semua pihak. Oleh sebab itulah, terbukti bahwa konsepsi teori keadilan Rawls pada intinya meliputi aspek kesamaan (equality) dan ketidaksamaan (inequality). Dengan didasarkan pada konsepsi keadilan sosial Rawls ini dapat mengakibatkan apabila terjadi suatu ketidaksamaan dapat saja ditoleransi apabila dapat menguntungkan semua pihak terutama golongan tertinggal.

6 Cappelletti, Mauro and Bryant Garth (Eds), Access To Justice: Book I, Supra Note 1, pp.1-7.

7 Rawls, John. A Theory Of Justice (Teori Keadilan), Cetakan Ke-2, (Bandung: Pustaka Setia, 2011), hlm. 9. 
Teori keadilan Rawls berangkat dari keyakinan intuitif yang dituangkannya dalam proposisi panjang yang pokok-pokoknya adalah: (1) Keadilan merupakan keutamaan utama institusi sosial, seperti kebenaran pada sistem berpikir kita. Hukum atau institusiinstitusi betapa pun bagus dan efisiennya apabila tidak adil haruslah diperbaiki atau dihapus. Benar dan adil adalah hal yang tidak bisa dikompromikan. (2) Setiap orang memiliki hak yang tertanam pada prinsip keadilan yang tidak boleh dilanggar sekalipun atas nama kepentingan umum. Keadilan tidak membenarkan dikorbankannya kepentingan seseorang atau sekelompok orang demi kepentingan orang banyak. (3) Dalam masyarakat berkeadilan, kemerdekaan dengan sendirinya terjamin; hak-hak yang dijamin oleh keadilan tidak bisa dijadikan mangsa tawar-menawar politik atau hitung-hitungan kepentingan umum. (4) Ketidakadilan dapat ditoleransi hanya apabila diperlukan untuk menghindari ketidakadilan yang lebih besar.

Bangsa yang beradab adalah bangsa yang menjalankan fungsi hukumnya secara merdeka dan bermartaba. ${ }^{8}$ Kehadiran hukum di dalam masyarakat di antaranya adalah untuk mengintegrasikan dan mengkoordinasikan kepentingan-kepentingan yang bisa bertubrukan satu sama lain itu oleh hukum diintegrasikan sedemikian rupa sehingga tubrukan-tubrukan itu bisa ditekan sekecilkecilnya. ${ }^{9}$

Pada hakikatnya, hukum merupakan norma, dan tiap-tiap norma pasti mengandung nilai yang tidak lain sebenarnya merupakan moral atau dalam lingkup yang lebih luas, moralitas. ${ }^{10}$ Lebih lanjut, aturan-aturan dari suatu sistem hukum harus sesuai dengan persyaratan-persyaratan substantif dari moralitas atau patokan baku lainnya. Aturanaturan hukum harus tunduk pada moralitas. ${ }^{11}$

Adnan Buyung Nasution memberikan pengertian bantuan hukum pada hakikatnya adalah sebuah program yang tidak hanya merupakan aksi kultural, akan tetapi juga aksi struktural yang diarahkan pada perubahan tatanan masyarakat yang lebih mampu memberikan nafas yang nyaman bagi golongan mayoritas. Oleh karena itu, bantuan hukum bukanlah masalah yang sederhana. Ia merupakan tindakan pembebasan masyarakat dari belenggu struktur politik ekonomi dan sosial yang sarat dengan penindasan.

Lembaga bantuan hukum merupakan lembaga non-profit yang pendiriannya bertujuan untuk memberikan pelayanan bantuan hukum secara gratis (cuma-cuma) kepada masyarakat yang membutuhkan bantuan hukum, namun tidak mampu bahkan

8 Muhammad Erwin, Filasafat Hukum: Refleksi Kritis Terhadap Hukum, Cetakan Ke-II, (Jakarta: Rajawali Pres, 2012), hlm. 132.

9 Satjipto Raharjo, Ilmu Hukum, Cetakan Ke-VII, (Bandung: Citra Aditya Bakti, 2012), hlm. 53.

10 Shidarta, Moralitas Profesi Hukum: Suatu Tawaran Kerangka Berpikir, (Bandung: Refika Aditama, 2006), hlm. 76-77.

11 Cahyadi, Antonius dan E. Fernando M. Manullang, Pengantar ke Filsafat Hukum, (Jakarta: Kencana, 2007), hlm. 52 . 
yang tidak mengerti hukum. Melalui gerakan bantuan hukum kita harus merebut Hak Asasi Manusia rakyat miskin yang telah cukup lama ditawan orang-orang kaya, meski harus disadari bahwa bantuan hukum saja tidak cukup.

Seiring dengan perkembangan zaman, masyarakat semakin meragukan kapasitas dan kapabilitas para penegak hukum dan lembaga peradilan di Indonesia, khususnya bagi kaum miskin. Maraknya perkara-perkara besar yang mencuat di muka umum, yang melibatkan petinggi petinggi negara dan orang-orang penting dalam proses berperkaranya di tengah jalan seolah lenyap ditelan bumi. Terlebih lagi, etika para penegak hukum yang sangat tidak patut dilakukan oleh seorang penegak hukum. Banyak ditemukan para penegak hukum yang rela mempertaruhkan tugas mulianya dengan nominal sejumlah uang. Hal-hal semacam inilah yang tidak dapat dihindarkan yang menyebabkan munculnya pesimisme masyarakat terhadap keadilan di negeri ini karena para penegak hukum yang tidak beretika.

Aparat penegak hukum dituntut untuk menjalankan tugasnya sesuai dengan apa yang dikatakan dalam undang-undang. Teori ini sebenarnya mendapatkan banyak kritik dari para ahli hukum, diantaranya adalah oleh Nonet dan Selznick yang berpendapat bahwa kritik terhadap hukum selalu mengarah pada ketidakmampuannya sebagai alat untuk mengatur perubahan dan untuk mengusahakan tercapainya keadilan. ${ }^{2}$

Di dalam Pasal 1 ayat (3) Undangundang Dasar 1945 ditegaskan bahwa Negara Indonesia adalah negara hukum. Negara hukum menjamin persamaan di hadapan hukum, mengakui serta melindungi hak asasi manusia. Oleh sebab itu, seluruh warga Indonesia memiliki hak untuk dapat diperlakukan sama di depan hukum (equality before the law). Persamaan bagi warga negara di hadapan hukum ini harus disertai dengan persamaan perlakuan (equal treatment). ${ }^{13}$ Oleh sebab itu, kita perlu merombak struktur yang jelas tidak adil dan menggantikannya dengan pola hubungan yang lebih adil. ${ }^{14}$

Berbicara tentang hakim dan putusan hakim di Indonesia, tidak bisa dilepaskan dari pembicaraan keadilan. Akses terhadap suatu keadilan merupakan salah satu bentuk pengejawantahan dari prinsip negara hukum dan pengakuan hak asasi manusia sebagaimana dijamin dalam Undang-undang Dasar Negara Republik Indonesia Tahun 1945. Hak-hak dan kewajiban-kewajiban yang dimiliki oleh warga negara Indonesia diharapkan dapat menjadi suatu kesatuan yang bertujuan untuk mewujudkan Indonesia yang adil sesuai sila keadilan sosial bagi seluruh rakyat Indonesia.

Konsep access to justice sendiri memiliki

12 R.B. Soemanto, Hukum dan Sosiologi Hukum, Pemikiran, Teori dan Masalah, (Solo: UNS Press, 2008), hlm. 145-146.

13 Moh. Irsyad Thamrin dan Moh. Farid, Panduan Bantuan Hukum Bagi Para Legal, (Yogyakarta: LBH Yogyakarta, 2010), hlm. 107.

14 Abdul Khakim dan Mulyana W, Beberapa Pemikiran mengenai Bantuan Hukum (Ke arah Bantuan Hukum Struktural), (Bandung: Alumni, 1981), hlm.13. 
dasar yang harus dapat diakses oleh semua kalangan dan harus menghasilkan suatu ketentuan yang adil bagi semua kalangan. Konsep access to justice mengutamakan gagasan pokok demi tercapainya suatu keadilan (social justice) bagi warga negara dari semua kalangan ${ }^{15}$ tanpa terkecuali. Pengecualian ini dimaksudkan bahwa access to justice tidak memandang perbedaan latar belakang, baik ras, agama, keturunan, pendidikan warga negara Indonesia dalam hal warga negara Indonesia mencari letak keadilan melalui lembaga peradilan. Seluruh warga negara Indonesia memiliki kesempatan dan/atau kemampuan yang sama di dalam mendapatkan access to justice. Meskipun pada akhirnya arti dari kata adil terkadang sulit diaplikasikan pada kehidupan nyata. Konsep access to justice juga berfokus pada tujuan dasar dari keberadaan suatu sistem hukum, yaitu dimana:

a. sistem hukum haruslah dapat diakses oleh seluruh kalangan warga negara Indonesia tanpa terkecuali;

b. sistem hukum haruslah dapat menghasilkan suatu ketentuan maupun keputusan yang dapat dirasakan adil bagi seluruh kalangan warga negara Indonesia (baik secara individual maupun kelompok).

Secara terminologis, konsep access to justice memiliki sebuah tujuan keadilan sosial (social justice) serta dapat mencegah dan menanggulangi kemiskinan sesungguhnya merupakan upaya adanya afirmatif action ${ }^{16}$ terhadap kelompok-kelompok rentan, terutama kaum miskin atau kaum yang tidak mampu. Berbagai upaya dilakukan agar dapat tercapainya suatu jaminan terhadap keadilan, salah satunya yaitu dengan cara pemulihan hukum (legal remedies) serta pemulihan peradilan (justice remedies). Jaminan terhadap suatu access to justice di Indonesia terkandung dalam pasal-pasal terkait hak asasi manusia dalam Undang-Undang Dasar 1945, Undang-undang Nomor 39 Tahun 1999 tentang Hak Asasi Manusia, Undang-undang Nomor 11 Tahun 2005 tentang Hak Ekonomi, Sosial dan Budaya serta Undang-undang Nomor 12 Tahun 2005 tentang Hak Sipil dan Politik dan Undang-undang Nomor 16 Tahun 2011 tentang Bantuan Hukum.

Secara garis besar pada umumnya permasalahan hukum yang banyak dialami oleh kaum atau golongan tidak mampu adalah tidak terpenuhinya hak-hak dasar mereka di berbagai bidang. Setidaknya ada empat permasalahan pokok akses terhadap hak ekonomi, sosial dan budaya yang salah satunya yaitu berkembangnya pandangan yang menyatakan bahwa hak ekonomi, sosial dan budaya merupakan hak yang tidak justiciable (tidak bisa dituntut secara hukum di pengadilan). Secara instrumentalis jaminan hak-hak ekonomi, sosial dan budaya

15 Sadiawati, Diani dan Mas Acmad Santosa, Strategi Nasional Akses Terhadap Keadilan. Cetakan Ke-1, (Jakarta: Bappenas, 2009), hlm. 1.

16 Kelompok Kerja Akses Terhadap Keadilan, Strategi Nasional Akses Terhadap Keadilan. (Jakarta: BAPPENAS Direktorat Hukum dan HAM, 2009), hlm. 5-6. 
juga mempunyai kelemahan mendasar

yang menganggap bahwa hak tersebut

pemenuhannya dilakukan secara bertahap (progresif realisation). ${ }^{17}$

Berangkat dari makin tertindasnya kaum atau golongan tidak mampu terutama dalam mencari keadilan di bidang hukum, peranan lembaga pelayanan hukum sangat dibutuhkan serta adanya lembaga-lembaga hukum yang melangsungkan pelatihan dan pendidikan hukum bagi kaum atau golongan tidak mampu. Para pengacara di negeri berkembang harus disadarkan bahwa mereka mengemban fungsi yang berjangkauan lebih jauh dari sekedar fungsi sebagai penasihat dan pembela dalam sistem hukum yang sudah mapan, yakni mereka harus mengembangkan budaya hukum. ${ }^{18}$

Bantuan hukum berdasarkan ketentuan Undang-undang Nomor 16 Tahun 2011 tentang Bantuan Hukum Pasal 1 angka 1 disebutkan bahwa bantuan hukum merupakan jasa hukum yang diberikan oleh Pemberi Bantuan Hukum secara cuma-cuma kepada Penerima Bantuan Hukum. Penerima Bantuan Hukum adalah orang atau kelompok orang miskin. Sedangkan Pemberi Bantuan Hukum adalah lembaga bantuan hukum atau organisasi kemasyarakatan yang memberi layanan Bantuan Hukum berdasarkan Undang-undang ini.
Undang-undang Nomor 16 Tahun 2011 tentang Bantuan Hukum menjadi payung hukum bagi lembaga bantuan hukum dalam pemberian bantuan hukum yang menunjang access to justice yang adil dan merata bagi setiap orang atau kelompok orang miskin yang tidak dapat memenuhi hak dasar secara layak dan mandiri, sesuai dengan ketentuan di dalam Pasal 5 ayat (1) Undang-undang Nomor 16 Tahun 2011 tentang Bantuan Hukum.

Pemberian bantuan hukum tidak sematamata diberikan kepada masyarakat miskin ketika mereka menghadapi perkara di muka persidangan. Bantuan hukum yang diberikan terhadap mencakup masalah hukum keperdataan, pidana maupun tata usaha negara. Jenis bantuan hukum yang diberikan pun ada 2 (dua) jenis, yaitu bantuan hukum di dalam persidangan atau yang lebih dikenal dengan litigasi dan bantuan hukum di luar persidangan atau yang lebih dikenal dengan istilah non litigasi.

Sesuai dengan ketentuan Pasal 4 ayat (3) Undang-undang Nomor 16 Tahun 2011 tentang Bantuan Hukum, ruang lingkup bantuan hukum yang diberikan kepada Penerima Bantuan Hukum meliputi menjalankan kuasa, mendampingi, mewakili, membela dan/atau melakukan tindakan hukum lain untuk kepentingan hukum Penerima Bantuan Hukum.

17 Sri Palupi, Problem dan Tantangan dalam Akses Hak Ekonomi, Sosial dan Budaya, Dalam Prasetyohadi dan Savitri Wisnuwardhani, ed., Penegakan Hak Asasi Manusia dalam 10 Tahun Reformasi. (Jakarta: Komnas HAM, 2008), hlm. 102-103.

18 Buyung Adnan, Bantuan Hukum di Indonesia, (Jakarta: LP3ES, 1982), hlm. 107-108. 
Bantuan hukum melalui jalur litigasi merupakan mekanisme penyelesaian perkara melalui jalur pengadilan dengan menggunakan pendekatan hukum (law approach) melalui aparat atau lembaga penegak hukum yang berwenang sesuai dengan aturan perundangundangan. ${ }^{19}$ Sedangkan bantuan hukum non litigasi merupakan mekanisme penyelesaian di luar eprsidangan, tetapi menggunakan mekanisme yang hidup dalam masyarakat yang bentuk dan macamnya sangat bervariasi, seperti cara musyawarah, perdamaian, kekeluargaan, penyelesaian adat dan lain-lain.

Bantuan hukum litigasi atau bantuan hukum dengan jalur persidangan sebenarnya diharapkan menjadi sebuah upaya the last resort atau ultimum remidium yakni upaya terakhir yang dapat dilakukan ketika upaya penyelesaian secara damai dan kekeluargaan tidak berhasil. Pada perkara pidana, bantuan hukum litigasi ini diberikan ketika ancaman pidana terdakwa lebih dari 5 tahun penjara. Ini merupakan bentuk jaminan pemberian hak-hak bagi terdakwa yang telah diakomodir oleh undang-undang dan bahkan pada tingkat penyidikan pun telah diberikan hak untuk dapat didampingi oleh penasihat hukum. Pemberian hak ini diakomodir oleh Kitab Undang-undang Hukum Acara Pidana (KUHAP) Pasal 56 ayat (1).

Di dalam praktek, terkadang seorang terdakwa sejak masih berstatus sebagai tersangka ketika diinformasikan akan haknya untuk didampingi oleh penasihat hukum, ia telah menolak sejak awal. Barulah ketika masuk di dalam proses persidangan dan ternyata ancaman hukumannya lebih dari 5 tahun, kemudian oleh Majelis Hakim pemeriksa perkara memberikan haknya untuk dapat didampingi oleh penasihat hukum, terdakwa tersebut ini menerima untuk didampingi penasihat hukum. Ini bersifat penunjukkan dari pihak pengadilan terhadap penasihat hukum si terdakwa. biasanya penasihat hukum yang ditunjuk adalah penasihat hukum yang berasal dari lembaga bantuan hukum yang telah bekerja sama dengan pihak pengadilan dengan program Pos Bantuan Hukum (POSBAKUM). Atau dapat saja, ketika ada satu atau beberapa orang lembaga bantuan hukum yang sedang bertugas piket, yang sedang bertugas piket inilah yang langsung ditunjuk sebagai penasihat hukum terdakwa.

Pemberian bantuan hukum pada jalur litigasi, khususnya pada perkara pidana bersifat mendampingi, bukan mewakili. Artinya, selama proses persidangan berlangsung, pihak lembaga bantuan hukum hanya mendampingi pemberi kuasa dan pemberi kuasa wajib hadir pada setiap persidangan. Sedangkan pemberian bantuan hukum pada jalur litigasi pada perkara perdata, lebih bersifat mewakili dan/atau mendampingi. Artinya, selama proses persidangan berlangsung, pihak lembaga bantuan hukum dapat mewakili

19 Bambang Sutiyoso, Hukum Arbitrase dan Alternatif Penyelesaian Sengketa, (Yogyakarta: Gama Media, 2008), hlm. 13 . 
dan/atau mendampingi pemberi kuasa dan pemberi kuasa tidak wajib hadir pada setiap agenda persidangan.

Pemberian bantuan hukum litigasi khususnya dalam perkara perdata inilah yang dapat mematahkan anggapan masyarakat bahwa memiliki perkara perdata pada tingkat pengadilan itu rumit, karena sesuai hukum acara yang berlaku para pihak yang berperkara harus membuat berkas (pada agenda jawab jinawab) walaupun dapat saja disampaikan secara lisan. Namun, ketika masyarakat telah menguasakan perkaranya pada lembaga bantuan hukum, seluruh berkas akan dibuat oleh lembaga bantuan hukum yang bertindak sebagai kuasa hukumnya. Meskipun tetap tidak dapat dipungkiri, berperkara melalui jalur litigasi memang membutuhkan waktu yang panjang karena dilakukan sesuai dengan prosedur hukum acara yang berlaku, menguras tenaga dan juga pikiran.

Prosedur atau mekanisme permohonan bantuan hukum ini pun sangat mudah, yaitu hanya dengan melampirkan surat keterangan tidak mampu yang dapat diurus sendiri oleh masyarakat yang tidak mampu dari tingkat RT, RW hingga tingkat kecamatan. Surat keterangan tidak mampu ini sebagai bukti nyata bahwa yang bersangkutan memang benar termasuk masyarakat yang tidak mampu.

Pada prakteknya, masyarakat awam mengetahui pemberian bantuan hukum hanya diberikan terhadap perkara litigasi saja. Masyarakat awam tidak mengetahui bahwa mereka berhak mendapatkan bantuan hukum pada wilayah non litigasi. Hal ini disebabkan minimnya pengetahuan mereka terhadap hak-hak mereka dan juga dikarenakan minimnya sosialisasi terhadap mereka akan hak-hak mereka ini.

Maraknya bermunculan berbagai lembaga bantuan hukum yang tergabung dalam sebuah wadah Organisasi Bantuan Hukum diharapkan dapat berperan maksimal di dalam menjalankan amanat Undang-undang Nomor 16 Tahun 2011 tentang Bantuan Hukum. Undang-undang Nomor 16 Tahun 2011 ini dapat pula dikatakan sebagai era revolusi access to justice bagi masyarakat miskin sebab melalui Undang-undang Nomor 16 Tahun 2011 tentang Bantuan Hukum inilah hak-hak masyarakat miskin khususnya hak akan bantuan hukum dapat lebih terjamin dan tersalurkan kepada mereka.

Di samping dengan hadirnya Undangundang Nomor 16 Tahun 2011 tentang Bantuan Hukum membawa dampak positif, akan tetapi undang-undang ini juga memiliki sisi negatif. Artinya, terdapat pasal di dalam undangundang ini yang dirasa menjadi kelemahan tersendiri. Pasal yang dimaksud yaitu Pasal 8 ayat (1), (2) huruf a, b. Pasal ini mengatur tentang persyaratan yang dipenuhi oleh lemabga bantuan hukum agar dapat menjadi Pemberi Bantuan Hukum. Persyaratan ini dapat saja menghambat proses access tojustice bagi kaum yang tidak mampu sebab masih banyak ditemui lembaga-lembaga bantuan hukum yang belum berbadan hukum, belum 
terakreditasi berdasarkan Undang-undang Nomor 16 Tahun 2011 tentang Bantuan Hukum. Dengan adanya pola akreditasi oleh undang-undang ini pun akan berampak pada jumlah kasus yang dapat ditangani oleh lembaga bantuan hukum yang bersangkutan.

Selain pemberian bantuan hukum melalui litigasi oleh lembaga bantuan hukum sebagai jalur access to justice, dapat pula ditempuh melalui jalur non litigasi. Penerapan bantuan hukum melalui jalur non litigasi ini dilakukan melalui upaya penyelesaian perkara dengan mengupayakan damai win win solution bagi kedua belah pihak. Selain itu, bantuan hukum non litigasi dapat pula dilakukan melalui kegiatan penyuluhan-penyuluhan hukum kepada warga masyarakat yang bertujuan agar warga masyarakat Indonesia menjadi sadar dan melek hukum. Bentuk penyuluhan hukum ini pun bermacam-macam. Penyuluhan hukum dapat dilakukan secara langsung (face to face) terhadap masyarakat atau dapat pula penyuluhan hukum ini dilakukan dengan menggunakan media elektronik yaitu penyuluhan hukum melalui radio atau televisi sehingga narasumber dapat berinteraksi langsung dengan masyarakat melalui telepon atau short message messager (SMS).

Bantuan hukum non litigasi juga dapat dilihat secara langsung di berbagai pengadilan, baik pengadilan negeri, pengadilan agama maupun pengadilan tata usaha negara yang bekerja sama dengan berbagai lembaga bantuan hukum. Bentuk pemberian bantuan hukum yang dimaksud di sini yaitu, lembaga- lembaga bantuan hukum melakukan kerjasama pengadaan program Pos Bantuan Hukum (POSBAKUM) dengan pengadilan terkait, akan membuka Pos Bantuan Hukum (POSBAKUM) yang bertujuan agar masyarakat umum khususnya masyarakat tidak mampu untuk dapat mengkonsultasikan permasalahan hukum yang dihadapinya.

Pelaksanaan program Pos Bantuan Hukum (POSBAKUM) di berbagai pengadilan baik pengadilan negeri, pengadilan agama maupun pengadilan tata usaha negara ini dirasa cukup efektif karena sebagian besar masyarakat Indonesia sungkan untuk menceritakan permasalahan hukum yang dihadapinya. Selain itu, faktor pemikiran bahwa apabila melakukan konsultasi bahkan sampai pada tingkat permohonan bantuan hukum di kantor advokat pasti akan menghabiskan biaya yang sangat besar. Dengan program Pos Bantuan Hukum (POSBAKUM) ini, masyarakat tidak dikenakan biaya sama sekali.

Mekanisme-mekanisme non litigasi inilah dirasa lebih dapat mudah masuk ke masyarakat karena dilakukan melalui pendekatan komunikatif dan di dukung pula oleh faktorfaktor lain yaitu besarnya rasa malu dan besarnya rasa takut dari masyarakat untuk melakukan konsultasi terkait masalah hukum (perkara) yang dihadapinya. Pendidikan dan penyuluhan hukum sebagai upaya preventif yang secara tidak langsung diharapkan dapat memberi solusi kepada seluruh masyarakat baik yang tersandung masalah hukum maupun yang tidak, agar mereka lebih mengerti solusi 
apa yang harus diambil di kemudian hari.

Proses penyelesaian suatu perkara dengan jalur pemberian bantuan hukum litigasi alangkah lebih baik apabila dijadikan sebagai suatu alternatif penyelesaian terakhir, sehingga upaya-upaya penyelesaian melalui jalur non litigasi akan dapat lebih dimaksimalkan lagi. Inilah yang seharusnya menjadi sebuah catatan penting bagi lembagalembaga bantuan hukum yang ada. Lembagalembaga bantuan hukum diharapkan dapat mengadvokasi masyarakat bahwa pemberian bantuan hukum merupakan upaya terakhir.

Dengan demikian, diharapkan keberadaan lembaga bantuan hukum dapat berperan serta sebagai salah satu wadah access to justice yaitu wadah bantuan hukum baik bantuan hukum di dalam persidangan (litigasi) maupun bantuan hukum di luar persidangan (non litigasi), di beberapa pengadilan pada akhirnya dapat membantu masyarakat khususnya masyarakat yang tidak mampu.

\section{Simpulan}

Bantuan hukum merupakan hak asasi setiap orang yang sedang tersandung kasus hukum sebagai suatu sarana dalam membela hak-hak konstitusional setiap orang dan merupakan suatu jaminan atas persamaan di muka hukum (equality before the law).
Dampak dari pemberian bantuan hukum ini sebagai perwujudan dari access to justice dan justice for all.

Ruang lingkup dalam pemberian bantuan hukum ini lebih tepat disasarkan bagi masyarakat yang kurang mampu karena sebagian besar dari mereka terkadang tidak mengetahui bahwa mereka memiliki hak yang sama di muka hukum. Dalam penyaluran bantuan hukum ini diperlukan peranan besar dari pemerintah agar tercapai pemerataan dalam menyalurkan bantuan hukum bagi masyarakat terutama bagi masyarakat yang tidak mampu.

Lembaga bantuan hukum berperan besar dalam access to justice bagi masyarakat yang tidak mampukarenaberperan besardalam memberikan solusi dari tingkat konsultasi, tingkat pendampingan bagi masyarakat di luar pengadilan (non-litigasi) hingga tingkat pendampingan bagi masyarakat di tingkat pengadilan (litigasi). Dengan adanya peranan lembaga bantuan hukum ini diharapkan dapat berperan serta dalam tercapainya fungsi bantuan hukum, pemerataan dana bantuan hukum, pemerataan siapa saja yang berhak mendapatkan dana bantuan hukum dan turut serta dalam mewujudkan lembaga hukum sebagai access to justice.

\section{DAFTAR PUSTAKA}




\section{Buku}

Ali, Mahrus. Membumikan Hukum Progresif.

Cetakan Ke-1. Yogyakarta: Aswaja Pressindo, 2013.

Buyung, Adnan. Bantuan Hukum di Indonesia .

Jakarta: LP3ES, 1982.

Cahyadi, Antonius dan E. Fernando M. Manullang. Pengantar ke Filsafat Hukum. Jakarta: Kencana, 2007.

Cappelletti, Mauro and Bryant Garth (Eds), Access To Justice: Book I. Supra Note 1.

Erwin, Muhammad. Filasafat Hukum: Refleksi Kritis Terhadap Hukum. Cetakan Ke-II. Jakarta: Rajawali Pres, 2012.

Huda, Nimatul. Hukum Tatanegara Indonesia. Jakarta: Raja Grafindo, 2005.

Hakim, Abdul dan Mulyana W. Beberapa Pemikiran mengenai Bantuan Hukum (Ke arah Bantuan Hukum Struktural). Bandung: Alumni, 1981.

Irsyad, Moh. Thamrin dan Moh. Farid. Panduan Bantuan Hukum Bagi Para Legal. Yogyakarta: LBH Yogyakarta, 2010.

Rawls, John. A Theory Of Justice (Teori Keadilan). Cetakan Ke-2. Bandung: Pustaka Setia, 2011.

Sadiawati, Diani dan Mas Acmad Santosa.

Strategi Nasional Akses Terhadap Keadilan. Cetakan Ke-1. Jakarta: Bappenas, 2009.

Shidarta. Moralitas Profesi Hukum: Suatu
Tawaran Kerangka Berpikir. Bandung: Refika Aditama, 2006.

Sudirman, Antonius. Hati Nurani Hakim dan Putusannya. Bandung: Citra Aditya Bakti, 2007.

Sutiyoso, Bambang. Hukum Arbitrase dan Alternatif Penyelesaian Sengketa. Yogyakarta: Gama Media, 2008.

Soemanto, R.B. Hukum dan Sosiologi Hukum, Pemikiran, Teori dan Masalah. Solo: UNS Press, 2008.

Raharjo, Satjipto. Ilmu Hukum. Cetakan Ke-VII. Bandung: Citra Aditya Bakti, 2012. . Sisi-Sisi Lain dari Hukum di Indonesia. Jakarta: Kompas, 2003.

\section{Makalah}

Djohanjah. Akses Pada Keadilan. Makalah pada Pelatihan HAM Jejaring Komisi Yudisial. Bandung: 30 Juni - 3 Juli 2010.

Palupi, Sri. Problem dan Tantangan dalam Akses Hak Ekonomi, Sosial dan Budaya, dalam Prasetyohadi dan Savitri Wisnuwardhani (Ed), Penegakan Hak Asasi Manusia dalam 10 Tahun Reformasi. Jakarta: Komnas HAM, 2008.

Kelompok Kerja Akses Terhadap Keadilan. Strategi Nasional Akses Terhadap Keadilan. Jakarta: BAPPENAS Direktorat Hukum dan HAM, 2009. 
Peraturan Perundang-undangan

Undang-undang Dasar Negara Republik Indonesia Tahun 1945.
Undang-undang Nomor 16 Tahun 2011 tentang Bantuan Hukum. 